\title{
First step to eradication of Poa annua L. from Point Thomas Oasis (King George Island, South Shetlands, Antarctica)
}

\author{
Halina Galera ${ }^{1}$ Maciej Wódkiewicz ${ }^{1} \cdot$ Ewa Czyż $^{1} \cdot$ Sławomir Lapiński $^{2}$ • \\ Maria Elżbieta Kowalska ${ }^{2}$ - Mariusz Pasik ${ }^{2}$ - Marcin Rajner ${ }^{2} \cdot$ Paweł Bylina $^{2}$ • \\ Katarzyna J. Chwedorzewska ${ }^{3}$
}

Received: 25 January 2016/Revised: 6 July 2016/Accepted: 6 July 2016/Published online: 4 August 2016

(C) The Author(s) 2016. This article is published with open access at Springerlink.com

\begin{abstract}
Poa апnиa, an alien species reported from the Antarctic continent and many Antarctic and sub-Antarctic islands, was accidentally introduced in the vicinity of the Polish Antarctic Station H. Arctowski. Recently the species has been found entering native plant communities. In almost 30 years it dispersed over $250 \mathrm{~m}$ from the site it was first observed and can therefore be considered invasive. We report the first steps to eradicate the species following the initial research to quantify the biology, ecology and genetics of the species. After detailed mapping of all 1439 tussocks located in the Arctowski Station area we removed 314 tussocks closest to a moss carpet formation (native plant community of high conservation value). All of the 49 tussocks growing in the Ecology Glacier forefield were removed. It is the biggest alien plant eradication act conducted so far in Antarctica. We plan to continue the eradication process and monitor the eradicated sites. This will provide valuable information on impacts and issues
\end{abstract}

Electronic supplementary material The online version of this article (doi:10.1007/s00300-016-2006-y) contains supplementary material, which is available to authorized users.

Katarzyna J. Chwedorzewska

kchwedorzewska@go2.pl

Halina Galera

h.galera@uw.edu.pl

1 Faculty of Biology, Biological and Chemical Research Centre, University of Warsaw, Żwirki i Wigury 101, 02-089 Warsaw, Poland

2 Faculty of Geodesy and Cartography, Warsaw University of Technology, Pl. Politechniki 1, 00-661 Warsaw, Poland

3 Department of Antarctic Biology, Institute of Biochemistry and Biophysics PAS, Pawińskiego 5a, 02-106 Warsaw, Poland related to removal of alien species in the maritime Antarctic and will help in informing future decisions on management of other plant invasions in the region. Given the increasing human traffic to the Antarctic and the associated risks of invasion our results will be important not only for Arctowski but also for the whole Antarctic region.

Keywords Роа аппиа · Alien species · Antarctica · Biological invasions

\section{Introduction}

Pоа аппиа L. (American common name: annual bluegrass, English common name: annual poa), an alien species to the Antarctic, was first reported in the vicinity of the Polish Antarctic Station H. Arctowski some 30 years ago (Olech 1996; Chwedorzewska et al. 2015). At Point Thomas Oasis $P$. аппиа inhabits anthropogenic sites, where the soil structure has been altered with equipment used for maintenance of the Station. The species also occupies humid sites sheltered from the wind where it is accompanied by two native flowering plants, Deschampsia antarctica Desv. and Colobanthus quitensis (Kunth) Bartl., and mosses such as Bryum pseudotriquetrum (Hedw.) P. Gaertn., B. Mey. \& Scherb. and Ceratodon purpureus (Hedw.) Brid. (Olech and Chwedorzewska 2011). Moreover, annual bluegrass produces viable caryopses, which may be fit to outcompete the local vascular plant seed germination (Wódkiewicz et al. 2013).

During the 2008/2009 austral summer an extensive population of $P$. аппиа was recorded on the deglaciated moraines of the Ecology Glacier, approximately $1.5 \mathrm{~km}$ from Arctowski at the area of Antarctic Specially Protected Area (ASPA) 128. This new population consisted of about 70 tussocks occupying about $100 \mathrm{~m}^{2}$ (Olech and 
Chwedorzewska 2011). In the 2014/2015 austral summer season several $P$. апnиа tussocks were found growing at the border of a moss carpet formation described by Furmańczyk and Ochyra (1982) and on a talus cone at the foot of rocky ledge Upłaz near the Station. Surveys were also undertaken of the Ecology Glacier area to determine that the previous reported $P$. аппиа plants were persisting.

Due to the danger of displacement of the species of especially valuable native plant communities we started an eradication project of $P$. аппиа in the Point Thomas Oasis area. The project was preceded by detailed necessary research investigating the biology of the species in accordance to guidelines regarding the eradication/control of alien species by Simberloff (2003a, b). The distribution, morphology, ecology, genetics, physiology, expansion history and potential sources of introduction of the species was determined through multi-author interdisciplinary studies (e.g., see Olech and Chwedorzewska 2011; Lityńska-Zając et al. 2012; MolinaMontenegro et al. 2014; Pastorczyk et al. 2014; Chwedorzewska et al. 2015; Giełwanowska and Kellmann-Sopyła 2015; Giełwanowska et al. 2015; Kellmann-Sopyła and Giełwanowska 2015; Kellmann-Sopyła et al. 2015). The research showed that the species is expanding in the anthropogenic sites as well as starts to invade native communities (Olech and Chwedorzewska 2011), has a distinctive morphological architecture in response to local harsh conditions (Galera et al. 2015) and produces a viable soil seed bank (Wódkiewicz et al. 2013, 2014). Роа аппиа has been accidentally introduced from Poland, and the population probably has been subsequently replenished from other sources like Argentina and Chile (where the part of cargo came from, Lityńska-Zając et al. 2012). This hypothesis seems to be supported by high level of genetic variability of Antarctic population (Chwedorzewska 2008; Chwedorzewska and Bednarek 2012). Therefore, this alien population may present a potential threat to the native flora.

This paper is a report of the activities carried out to prevent further spread of $P$. аппиа into natural habitats on King George Island and the preliminary attempt at eradication. By initializing this action we aim to eradicate the species from sites established close to native vegetation, and also collate information on the management of this species for future management of new invasions to Antarctica given the increasing human activity (e.g., Hughes et al. 2015). In this way our research gained a practical aspect for the conservation of the studied system.

\section{Materials and methods}

During the Antarctic summer season of 2014/2015 detailed searches were carried out at the Point Thomas Oasis. The position of $P$. аппиа sites was measured by GNSS technology. Additionally ground surveys were used to establish a permanent grid of $10 \times 10 \mathrm{~m}$ in the vicinity of the Arctowski Station $\left(62^{\circ} 09^{\prime} 41^{\prime \prime} \mathrm{S}, 58^{\circ} 28^{\prime} 10^{\prime \prime} \mathrm{W}\right)$. The grid covered the whole area adjacent to the Station buildings where $P$. апnиa tussocks were present. Distribution of $P$. аппиа within Arctowski Station (Fig. 1) is based on a map (scale 1:500) prepared by the Faculty of Geodesy and Cartography of Warsaw University of Technology during the XXXIX Polish Antarctic Expedition.

Subsequently plants from the southern part of the extant population which was closest to the moss carpet formation were removed. This was the area with the highest conservation value given its proximity to native vegetation, unlike the remaining Arctowski area which is highly modified by anthropogenic activity. The removal was conducted by hand by qualified scientific staff ( 2 persons) carefully not to disturb native plant species. Plants were eradicated before they produced flowers to prevent seed set and dispersal (from 3 February to 17 March 2015). All sites of $P$. аппиа tussock removal were mapped (Fig. 1) and marked in the field by pins. We defined a site as a group of tussocks separated from each other by no more than $0.5 \mathrm{~m}$. Two sites located on the road frequented by Station vehicles were not pinned.

Height and width of tussocks were measured in the field. Each tussock was dug up with the roots, transported to the Station laboratory and washed to dispose of the soil. Subsequently removed tussocks were disintegrated to check the number of individual plants forming them. All collected specimens were placed in silica gel and transported to Poland for further studies (after germination experiments the samples will be incinerated in Poland). Our earlier research (Wódkiewicz et al. 2014) indicated that the structure of the soil seed bank is highly associated with the location of tussocks. We can therefore expect that additional topsoil removal from underneath the tussocks should efficiently restrict population recover from the soil seed bank. Therefore, the eradication was carried out in two methods: (1) removal of plants and (2) removal of plants and the associated upper soil layer (approximately $0-10 \mathrm{~cm}$ ) from underneath of plants. This scheme allows for future observations of the eradication success of these two methods and potential recruitment of plants from the soil seed bank.

All the tussocks from the forefield of Ecology Glacier were removed according to the scheme described above. The location of their removal sites has been marked by pins and their GNSS coordinates to monitor recovery of the sites in future. All field activities took 9 days (subject to interruptions due to severe weather conditions) work of two experienced scientists. We assess the workload to amount to 50 person-hours in the field and additional 50 personhours in the laboratory. 
Fig. 1 Distribution of $\mathrm{Poa}$ аппиа in the vicinity of Arctowski Station (Point Thomas Oasis) in 2014/2015 austral summer. Location of the studied site on King George Island marked with a star on the insert map. Poa апnua removal site numbers correspond to numbers in Section A of Online Resource 1

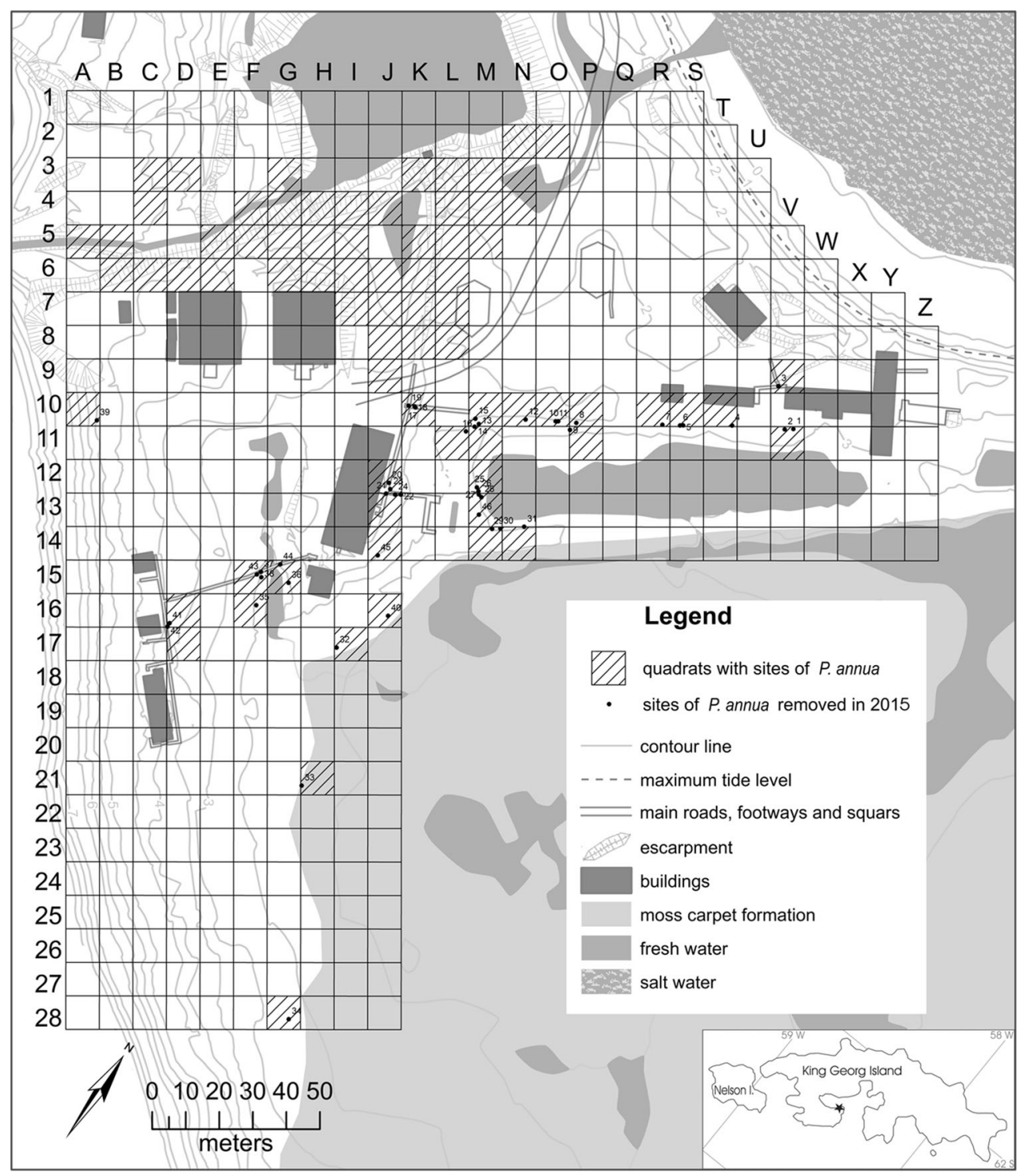

\section{Results}

The population of $P$. апnиа near the Station constituted of 1439 tussocks. 314 of them were removed from 46 sites (see Fig. 1 and section A in Online Resource 1). We have eradicated about $25 \%$ of $P$. апnиа population in Point Thomas Oasis. The eradicated tussocks consisted altogether of 636 P. аnnua individuals with an average of 2.03 individuals per tussock and a maximum of 36 individuals recorded in one tussock. The average diameter of removed tussocks was $1.4 \mathrm{~cm}$. The removed tussocks grew in various environmental conditions: vicinity of buildings, roads, fresh water bodies, near moss carpet formation (see Fig. 1) and on the deglaciated moraine of Ecology Glacier (Online resource 1). Our morphometric measurements may be therefore considered representative for Point Thomas Oasis annual bluegrass population.
At the forefield of Ecology Glacier P. апnиa was found growing at five sites: $62^{\circ} 10^{\prime} 02.5^{\prime \prime} \mathrm{S}, 58^{\circ} 27^{\prime} 50.8^{\prime \prime} \mathrm{W}$ (site 1); $62^{\circ} 10^{\prime} 03.6^{\prime \prime} \mathrm{S}, \quad 58^{\circ} 27^{\prime} 49.3^{\prime \prime} \mathrm{W}$ (site 2); $62^{\circ} 10^{\prime} 03.9^{\prime \prime} \mathrm{S}$, $58^{\circ} 27^{\prime} 49.9^{\prime \prime} \mathrm{W}$ (site 3); $62^{\circ} 10^{\prime} 03.5^{\prime \prime} \mathrm{S}, 58^{\circ} 27^{\prime} 49.6^{\prime \prime} \mathrm{W}$ (site 4); $62^{\circ} 10^{\prime} 03.6^{\prime \prime} \mathrm{S}, 58^{\circ} 27^{\prime} 49.6^{\prime \prime} \mathrm{W}$ (site 5). All of the 49 found tussocks consisting of 57 individuals have been removed (section B in Online Resource 1). The maximum number of individuals in one tussock was seven.

The distribution map of $P$. апnиa in the vicinity of buildings at Arctowski Station in the austral growing season of 2014/2015 indicates the presence of tussocks in 76 quadrates neighboring the buildings (Fig. 1). Numerous tussocks occurred on the border of anthropogenic sites (roads and road sides). Several sites have been recorded in the immediate vicinity of a native plant community-moss carpet formation (see Fig. 1-sites: 32 in quadrate I-17, 33-quadrate H-21, 34-quadrate G-28 and 40-quadrate 
J-16). One site occurred on the edge of a talus cone at the foot of a rocky ledge Uplaz bordering the Station premises (site 39 located in quadrate A-10).

Comparison of the present distribution of $P$. annua in the Point Thomas Oasis with data on the first occurrence highlights the dynamic nature of the species and changes in its spatial distribution. Poa апnua was first recorded at the entrance to the main Station building (first record-austral summer of 1985-1986, Olech 1996). Presently there are no tussocks at this location (quadrate Y-10, Fig. 1). The distance between the location of the first tussock recorded in Point Thomas Oasis and the most distant tussock recorded in this study (site no 34, quadrate G-28, see Fig. 1) is more than $250 \mathrm{~m}$. Plants growing on the deglaciated moraines of the Ecology Glacier (first recorded in this locality in the austral summer 2008/2009) were even further away (around $1.5 \mathrm{~km}$ ) from the location of the first occurrence of this species at Arctowski Station (Olech and Chwedorzewska 2011; Chwedorzewska et al. 2015). The initial genetic research indicated that their diaspores have been most probably accidentally introduced from the vicinity of the Station.

\section{Discussion}

Invasive species eradication or control is more feasible on islands when the species occupies still a small area at the beginning of the invasion process and with limited opposition from the society (Rejmánek and Pitcairn 2002; Simberloff 2003a). The $P$. annua population at Point Thomas Oasis presents all the above-stated characteristics which make the control/eradication effort still a realistic goal.

Annual bluegrass is the most widespread alien plant occurring on sub-Antarctic and Antarctic islands (Frenot et al. 2005; Chwedorzewska et al. 2015). The species has been reported from all major sub-Antarctic island groups and is invasive on many of them (e.g., Gremmen and Smith 1999; Frenot et al. 2001, 2005; Williams et al. 2013). In maritime Antarctic the species has been observed on King George Island (Olech 1996), Deception Island (Skottsberg 1954; Longton 1966) and at couple of locations at Antarctic Peninsula (Molina-Montenegro et al. 2012).

Richardson et al. (2000) defined "invasive" as "Naturalized plants that produce reproductive offspring, often in very large numbers, at considerable distances from parent plants (approximate scales: $>100 \mathrm{~m} ;<50$ years for taxa spreading by seeds and other propagules [...]), and thus have the potential to spread over a considerable area." Naturalized (established) species are considered to be "Those alien species, that sustain self-replacing populations for several life cycles or a given period of time
(10 years is advocated for plants) without direct intervention by people, or despite human intervention" (Richardson et al. 2000). Our results indicate that in the vicinity of Arctowski Station annual bluegrass has spread on a distance of over $250 \mathrm{~m}$ during 30 years and sustains a selfreplacing population. If we extrapolate the average number of individuals per tussock (about 2) from the eradicated sites onto the whole population thriving at Arctowski Station (more than 1400 tussocks have been recorded during the 2014/2015 growing season), then the population size may be estimated to over 2800 individuals. A further 57 P. annua individuals grew at the forefield of Ecology Glacier (ASPA 128) — at a distance of around $1.5 \mathrm{~km}$ from the location of the initial detection on King George Island. The spatial and temporal dynamics of annual bluegrass spread is sufficient to declare the species invasive at the scale of Point Thomas Oasis. It is, however, necessary to admit that this spreading is not exceptionally intense in the sense of area occupied with time or the density of plant cover in comparison with other alien plant invasions worldwide.

Many authors acknowledge that the impact on the native ecosystems and threat to native biological diversity are important components of the "invasive" definition [compare, e.g., Richardson et al. 2000; Frenot et al. 2005; Keller et al. 2011 and definitions of invasion used by Invasive Species Specialist Group-see About invasive species (2008)]. Gremmen (1997) reported that he observed $P$. annua to compete with undisturbed natural vegetation on Marion Island (sub-Antarctic). So far no clear evidence on the negative impact of $P$. annua on the native vegetation of King George Island has been detected. Only the results of Molina-Montenegro et al. (2012) show indirectly that there is a possibility of effective competition for resources and/or space between $P$. annua and $D$. antarctica or $C$. quitensis (native flora of Antarctica contains only these two species of flowering plants). However, in the habitat under question species relations may not be driven by competition.

Species entering natural and semi-natural environments are classified invasive (e.g., Richardson et al. 2000; Frenot et al. 2005; About invasive species 2008) and such is the case of $P$. annua at Arctowski. That the species started to disperse from anthropogenic habitats into natural environments was the main reason for initiating eradication of the species from ASPA 128 and from the vicinity of the Station.

Invasive species should exhibit specific adaptations enabling its persistence and population development in new conditions. Shah and Shaanker (2014) state that "Species could be regarded as invasive only when after adaptation in non-native habitats they reach yet another fitness maximum." In the case of $P$. annua some functional traits typical of the species proved to be advantageous in 
polar conditions (see Giełwanowska et al. 2011; Chwedorzewska et al. 2015). The ability of this species to persist on King George Island may be attributed to such traits as: significant increase in frequency of epigenetic variability (Chwedorzewska and Bednarek 2012), unique phenotypic response (Galera et al. 2015) and high concentration of soluble carbohydrates in plant vegetative organs (Pastorczyk et al. 2014) as well as in seeds that "can be a metabolic future indicating the readiness of caryopses to start of germination in short period of favorable growing conditions" (Kellmann-Sopyła et al. 2015). Annual bluegrass is preconditioned to successful establishment in the region and maintains a soil seed bank in the Antarctic (Wódkiewicz et al. 2013, 2014).

Hughes et al. (2015) pointed out the necessity of eradication of $P$. annua at Arctowski; however, they stated that from the Polish operator "no attempt at eradication has been reported." Their manuscript submission was received by the editorial staff on January 5, 2015 and published online on March 10, 2015 (Hughes et al. 2015) we were working on the initial steps of eradication just as snow cover retreated in February and March 2015 (see report: Eradication of a nonnative grass $P$. аппиа L. from ASPA No 128 Western Shore of Admiralty Bay, King George Island, South Shetland Islands 2015). All of our earlier research regarding the biology and genetics of $P$. апnua at Arctowski (Olech and Chwedorzewska 2011; Lityńska-Zając et al. 2012; Wódkiewicz et al. 2013, 2014; Molina-Montenegro et al. 2014; Pastorczyk et al. 2014; Chwedorzewska et al. 2015; Galera et al. 2015; Giełwanowska et al. 2015; Kellmann-Sopyła et al. 2015; Kellmann-Sopyła and Giełwanowska 2015) was aimed at informed eradication/control of the species. Our actions preceded by the stated initial research enabled an analysis of the invasion process in the Antarctic and provided detailed documentation of eradication. This presents added value for detection, control and/or eradication of any new potential other newcomers (Chwedorzewska et al. 2015).

Negative impact of $P$. апnиa eradication campaign from Point Thomas Oasis was negligible (compare Hughes et al. 2015 with our report - see Eradication of a non-native grass P. anпиа L. from ASPA No 128 Western Shore of Admiralty Bay, King George Island, South Shetland Islands 2015). The collective area disturbed (up to $10 \mathrm{~cm}$ deep) during the eradication was small $\left(0.1 \mathrm{~m}^{2}\right.$ at the Station and $0.0025 \mathrm{~m}^{2}$ at the Ecology Glacier forefield, see Online Resource 1).

The eradication of Poa pratensis L. at Cierva Point has been conducted at the same time (see The successful eradication of $P$. pratensis from Cierva Point, Danco Coast, Antarctic Peninsula 2015). This eradication involved the removal of 1 continuous patch $\left(0.53 \mathrm{~m}^{2}\right.$, Pertierra et al. 2013). Our work included a much larger area to be searched as $P$. annua at Arctowski has a dispersed spatial distribution with many more tussocks (Fig. 1). So far this is the biggest eradication act conducted in Antarctica. Our action is further continued (see Next step in eradication of non-native grass $P$. annua L. from ASPA No 128 Western Shore of Admiralty Bay, King George Island, South Shetland Islands 2016), and subsequent reports will be prepared with eradication progress.

The time from taking action to total or partial eradication of an alien species is problematic (Rejmánek and Pitcairn 2002; Brooks 2007). There is an evident trade-off between taking immediate action and an action postponed in order to gather information necessary for successful eradication. With time the former may prove to be inadequately prepared and therefore ineffective. The later on the other hand may be performed too late and also be ineffective. The choice is not at all straightforward (see Simberloff 2003a: "For success in some eradication campaigns, rapid reinvasion must be unlikely; in other instances the economics of the situation may make the attempt worthwhile even if reinvasion ensues"). In the maritime Antarctic annual bluegrass has only established on King George Island. All the other records indicate only a transient appearance of this species (Molina-Montenegro et al. 2012; Chwedorzewska et al. 2015). The expansion of $P$. апnиa at on King Georg Island may be an example of "boom and bust" dynamics (Blackburn et al. 2011). Defining species dynamics would require further long term observations, what could lead to demographic explosion of the species. Therefore, we decided to commence a wide scope eradication action in the Point Thomas Oasis acting now was thought necessary given: "even a moderate increase in resources for early detection and eradication of invasive weeds would be the most profitable investment" (Rejmánek and Pitcairn 2002; see also Simberloff 2003a). Similarly Molina-Montenegro et al. (2012) have eradicated P. annua occurring near Chilean stations in 2009/2010 austral summer-after performing their field research.

Molina-Montenegro et al. (2015) suggested that future repeated colonization may disable effective eradication of the species with there being only the possibility to control. Our research at Arctowski will identify whether recolonization is from external sources or from the soil seed bank and how long it takes for depletion of the seed store in soil. It is worth noting that the biology of the species (i.e., autogamy, seed persistence, small seed size, minimal requirements for germination, short life cycle, small plant size) may still hamper effective total eradication.

\section{Conclusions}

For a couple of years $P$. annua has been classified as an invasive species on King George Island (Chwedorzewska and Bednarek 2012; Molina-Montenegro et al. 2014; 
Chwedorzewska et al. 2015). Our research shows that the species exhibits the characteristics of invasion given the documented spread over time in the Point Thomas Oasis.

Our findings are important not only for Point Thomas Oasis, but also for a broader Antarctic context as the species is reported from many locations (e.g., Molina-Montenegro et al. 2012). The species may be introduced and escape detection on various islands in the region, with similar environmental factors, due to the remoteness of these sites. Research undertaken at Point Thomas Oasis identifies the need for $P$. annua eradication from such sites. The process will be continued in successive years upon Polish Station Operator consent. We propose the successive removal of $P$. annua patches from the vicinity of the Station as well as monitoring sites where annual bluegrass has been eradicated in the 2014/2015 growing season. Presently Point Thomas Oasis remains a testing ground on actions to be taken when the eradication process is not started at the initial stage of invasion.

Acknowledgments We thank members of the 39th Polish Antarctic Expedition for assistance and support in our field work. We also thank Prof. Dieter Piepenburg (Editor-in-Chief of the Journal), Dr Justine Shaw, Dr Ad H.L. Huiskes and one anonymous reviewer for a detailed and throughout review, language correction suggestions and valuable comments on our manuscript. This research project was supported by Polish Ministry of Scientific Research and Higher Education by a Grant No. 218361. Part of this study was carried out at the Biological and Chemical Research Centre, University of Warsaw, established within a project co-financed by the EU European Regional Development Fund under the Innovative Economy Operational Program, 2007-2013.

Open Access This article is distributed under the terms of the Creative Commons Attribution 4.0 International License (http://crea tivecommons.org/licenses/by/4.0/), which permits unrestricted use, distribution, and reproduction in any medium, provided you give appropriate credit to the original author(s) and the source, provide a link to the Creative Commons license, and indicate if changes were made.

\section{References}

About invasive species (2008) In: Global invasive species database. http://interface.creative.auckland.ac.nz/database/welcome/con tent.asp. Accessed 07 June 2016

Blackburn TM, Pyšek P, Bacher S, Carlton JT, Duncan RP, Jarošik V, Wilson JRU, Richardson DM (2011) A proposed unified framework for biological invasions. Trends Ecol Evol 26:333-339

Brooks ML (2007) Effects of land management practices on plant invasions in wildland areas. In: Netwig W (ed) Biological invasions. Ecological studies 193. Springer, Heidelberg, pp 147-162

Chwedorzewska KJ (2008) Poa annua L. in Antarctic-searching for the source of introduction. Polar Biol 31:263-268. doi:10.1007/ s00300-007-0353-4

Chwedorzewska KJ, Bednarek PT (2012) Genetic and epigenetic variation in a cosmopolitan grass (Poа апnиa L.) from Antarctic and Polish populations. Pol Polar Res 33:63-80. doi:10.2478/ v10183-012-0004-5

Chwedorzewska KJ, Giełwanowska I, Olech M, Wódkiewicz M, Molina-Montenegro M, Galera H (2015) Роа аппиа L. in the maritime Antarctic-an overview. Polar Rec 51:637-643. doi:10.1017/S0032247414000916

Eradication of a non-native grass Poa аппиа L. from ASPA No 128 Western Shore of Admiralty Bay, King George Island, South Shetland Islands (2015) In: Final report of the thirty-eighth Antarctic Treaty consultative meeting, Sofia, 1-10 June 2015, vol 2. Secretariat of the Antarctic Treaty, Buenos Aires, IP078. http://www.ats.aq/documents/ATCM38/fr/ATCM38_fr002_e. pdf. Accessed 26 May 2016

Frenot Y, Gloaguen JC, Massé L, Lebouvier M (2001) Human activities, ecosystem disturbance and plant invasions in sub-Antarctic crozet, Kerguelen and Amsterdam Islands. Biol Conserv 101:33-50. doi:10.1016/S0006-3207(01)00052-0

Frenot Y, Chown SL, Whinam J, Selkirk PM, Convey P, Skotnicki M, Bergstrom DM (2005) Biological invasions in the Antarctic: extent, impacts and implications. Biol Rev 80:45-72. doi:10. 1017/S1464793104006542

Furmańczyk K, Ochyra R (1982) Plant communities of the Admiralty Bay region (King George Island, South Shetland Islands, Antarctic) I. Jasnorzewski Gardens. Pol Polar Res 3:25-39

Galera H, Chwedorzewska KJ, Wódkiewicz M (2015) Response of Poa аппиа to extreme conditions: comparison of morphological traits between populations from cold and temperate climate conditions. Polar Biol 38:1657-1666. doi:10.1007/s00300-015-1731-y

Giełwanowska I, Kellmann-Sopyła W (2015) Generative reproduction of Antarctic grasses, the native species Deschampsia antarctica Desv. and the alien species Poa annua L. Pol Polar Res 36:261-279. doi:10.1515/popore-2015-0016

Giełwanowska I, Pastorczyk M, Kellmann-Sopyła W (2011) Influence of environmental changes on physiology and development of polar vascular plants. Pap Glob Change IGBP 18:53-62. doi:10. 2478/v10190-010-0005-6

Giełwanowska I, Pastorczyk M, Kellmann-Sopyła W, Górniak D, Górecki RJ (2015) Morphological and ultrastructural changes of organelles in leaf mesophyll cells of the Arctic and Antarctic plants of Poaceae family under cold influence. Arct Antarct Alp Res 47:17-25. doi:10.1657/AAAR0014-019

Gremmen NJM (1997) Changes in the vegetation of sub-Antarctic Marion Island resulting from introduced vascular plants. In: Battaglia B, Valencia J, Walton DWH (eds) Antarctic communities: species, structure and survival. Cambridge University Press, Cambridge, pp 417-423

Gremmen NJM, Smith VR (1999) New records of alien vascular plants from Marion and Prince Edward Islands, sub-Antarctic. Polar Biol 21:401-409

Hughes KA, Pertierra LR, Molina-Montenegro MA, Convey P (2015) Biological invasions in terrestrial Antarctica: what is the current status and can we respond? Biodivers Conserv 24:1031-1055. doi:10.1007/s10531-015-0896-6

Keller RP, Geist J, Jeschke JM, Kühn I (2011) Invasive species in Europe: ecology, status, and policy. Environ Sci Europe 23:23. http://www.enveurope.com/content/23/1/23

Kellmann-Sopyła W, Giełwanowska I (2015) Germination capacity of five polar Caryophyllaeae and Poaceae species under different temperature conditions. Polar Biol 38:1753-1765. doi:10.1007/ s00300-015-1740-x

Kellmann-Sopyła W, Lahuta LB, Giełwanowska I, Górecki RJ (2015) Soluble carbohydrates in developing and mature diaspores of polar Caryophyllaceae and Poaceae. Acta Physiol Plant 37:118. doi:10.1007/s11738-015-1866-Z

Lityńska-Zając M, Chwedorzewska KJ, Olech M, Korczak-Abshire M, Augustyniuk-Kram A (2012) Diaspores and phyto-remains 
accidentally transported to the Antarctic station during three expeditions. Biodivers Conserv 21:3411-3421. doi:10.1007/ s10531-012-0371-6

Longton RE (1966) Alien vascular plants on Deception Island, South Shetland Islands. Br Antarct Surv B 9:55-60

Molina-Montenegro MA, Carrasco-Urra F, Rodrigo C, Convey P, Valladares F, Gianoli E (2012) Occurrence of the non-native annual bluegrass on the Antarctic mainland and its negative effects on native plants. Conserv Biol 26:717-723. doi:10.1111/ j.1523-1739.2012.01865.x

Molina-Montenegro MA, Carrasco-Urra F, Acuña-Rodríguez I, Oses R, Chwedorzewska KJ (2014) Assessing the importance of human activities for the establishment of the invasive Poa апnиа in the Antarctica. Polar Res 33:21425. doi:10.3402/polar.v33. 21425

Molina-Montenegro MA, Pertierra LR, Razeto-Barry P, Díaz J, Finot VL, Torres-Díaz C (2015) A recolonization record of the invasive Poа аппиа in Paradise Bay, Antarctic Peninsula: modeling of the potential spreading risk. Polar Biol 38:1091-1096. doi:10.1007/s00300-015-1668-1

Next step in eradication of non-native grass Роа аппиа L. from ASPA No 128 Western Shore of Admiralty Bay, King George Island, South Shetland Islands (2016) In: Thirty-ninth Antarctic Treaty consultative meeting — nineteenth committee on environmental protection meeting, Santiago, 23 May 2016-01 June 2016, ATCM XXXIX-CEP XIX - meeting documents, IP060. http:// www.ats.aq/documents/ATCM39/ip/ATCM39_ip060_e.doc

Olech M (1996) Human impact on terrestrial ecosystems in west Antarctica. Proc NIPR Symp Polar Biol 9:299-306

Olech M, Chwedorzewska KJ (2011) The first appearance and establishment of alien vascular plant in natural habitats on the forefield of retreating glacier in Antarctica. Antarct Sci 23:153-154. doi:10.1017/S0954102010000982

Pastorczyk M, Giełwanowska I, Lahuta LB (2014) Changes in soluble carbohydrates in polar Caryophyllaceae and Poaceae plants in response to chilling. Acta Physiol Plant 36:1771-1780. doi:10. 1007/s11738-014-1551-7

Pertierra LR, Lara F, Benayas J, Hughes KA (2013) Poa pratensis L., current status of the longest-established nonnative vascular plant in the Antarctic. Polar Biol 36:1473-1481. doi:10.1007/s00300013-1367-8

Rejmánek M, Pitcairn MJ (2002) When is eradication of exotic pest plants a realistic goal? In: Veitch CR, Clout MN (eds) Turning the tide: the eradication of invasive species. IUCN SSC Invasive Species Specialist Group. IUCN, Gland, Cambridge

Richardson DM, Pyšek P, Rejmánek M, Barbour MG, Panetta FD, West CJ (2000) Naturalization and invasion of alien plants: concepts and definitions. Divers Distrib 6:93-107. http://www. blackwell-science.com/ddi

Shah MA, Shaanker RU (2014) Invasive species: reality or myth? Biodivers Conserv 23:1425-1426. doi:10.1007/s10531-0140673-y

Simberloff D (2003a) Eradication-preventing invasions at the outset. Weed Sci 51:247-253

Simberloff D (2003b) How much information on population biology is needed to manage introduced species? Conserv Biol 17:83-92. doi:10.1046/j.1523-1739.2003.02028.x

Skottsberg C (1954) Antarctic vascular plants. Bot Tidsskr $51: 330-338$

The successful eradication of Poa pratensis from Cierva Point, Danco Coast, Antarctic Peninsula (2015) In: Final report of the thirtyeighth Antarctic Treaty consultative meeting, Sofia, 1-10 June 2015, vol 2. Secretariat of the Antarctic Treaty, Buenos Aires, IP029. http://www.ats.aq/documents/ATCM38/fr/ATCM38_ fr002_e.pdf. Accessed 26 May 2016

Williams L, Kristiansen P, Shaw J, Sindel B, Wilson SC (2013) Weeds down under: invasion of the sub-Antarctic wilderness of Macquarie Island. Plant Prot Q 28:71-72

Wódkiewicz M, Galera H, Giełwanowska I, Chwedorzewska KJ, Olech M (2013) Diaspores of the introduced species Poа аппиа L. in soil samples from King George Island (South Shetlands, Antarctic). Arct Antarct Alp Res 45:415-419. doi:10.1657/19384246-45.3.415

Wódkiewicz M, Ziemiański M, Kwiecień K, Chwedorzewska KJ, Galera H (2014) Spatial structure of the soil seed bank of Poa апnиа L.- alien species in the Antarctica. Biodivers Conserv 23:1339-1346. doi:10.1007/s10531-014-0668-8 